\title{
The summer diet of moose Alces alces in Agder, south Norway - the link to fragile bones and kidney damages?
}

\author{
Magnar BJERGA* and Atle MYSTERUD**
}

\begin{abstract}
Bjerga M. and Mysterud A. 1999. The summer diet of moose Alces alces in Agder, south Norway - the link to fragile bones and kidney damages? Acta Theriologica 44: $107-111$
\end{abstract}

Reported cases of fragile bones and kidney damage from the Agder counties, south Norway, motivated this study of the diets of radio-collared moose Alces alces Linnaeus, 1758 during summer 1995. Birch Betula pubescens (39.8\%), bilberry Vaccinium myrtillus (13.3\%), and bog asphodel Narthecium ossifragum (10.8\%) were the main plants eaten, but only birch and bog asphodel were preferred when use was compared to relative availability. Bog asphodel is highly toxic and has been reported to cause severe kidney damage in domestic sheep Ovis aries and cattle Bos taurus. Hence, we hypothesized high levels of bog asphodel in the diet of moose in Agder is the link to kidney damage frequently reported from this area. However, laboratory studies have not documented damage to the skeleton from high intake of this species, and we therefore hypothesized fragile bones are caused by other factors than eating bog asphodel.

Department of Biology, Division of Zoology, University of Oslo, P.O. Box 1050 Blindern, N-0316 Oslo, Norway, fax: 47-22 8546 05, e-mail: atle.mysterud@bio.uio.no

Key words: Alces alces, bog asphodel, food selection, health condition, toxicity

\section{Introduction}

Moose Alces alces Linnaeus, 1758 populations have grown extremely rapidly in Scandinavia during the last few decades (eg Cederlund and Markgren 1987). The increase in density has lead to a decrease in body weights in several areas in Scandinavia, probably due to density-dependent food limitation (Sand 1996). The health of moose in Scandinavia is usually regarded as good, but there is growing concern because moose in Aust- and Vest-Agder counties in southern Norway have an 8 times higher incidence of broken bones than moose in control areas (Punsvik 1993, 1994). Several dead moose carcasses with kidney damage (toxic nephrosis) have also been found (T. Vikøren, K. Handeland, G. Stuve and B. Bratberg, unpubl.).

As part of a larger project studying the causes of the poor condition of moose in the Agder counties (Fjeld et al. 1997), the food selection of radio-collared moose

\footnotetext{
*Present address: Miljøvernavdelingen, Hole kommune, 3530 Riøse, Norway, e-mail: magnarbj@hotmail.com **Correspondence author
} 
was followed during summer of 1995. Our objective was to identify possible links between the summer diet and fragile bones and kidney damage.

\section{Study area}

The study area was situated in Bygland municipality in Aust-Agder county, southern Norway, between $58^{\circ} 49^{\prime}-58^{\circ} 58^{\prime} \mathrm{N}$ and $7^{\circ} 43^{\prime}-7^{\circ} 56^{\prime} \mathrm{E}$. The topography is varied and elevation varies from $200 \mathrm{~m}$ to $936 \mathrm{~m}$ a.s.l. Acid bedrock dominates in the region, and the soil layer is thin (Abrahamsen et al. 1977). In the areas with productive forest, $34 \%$ of the soil is of low, $48 \%$ of medium and $18 \%$ of high site quality with regard to forest production (Agder Skogeigarlag 1987). The vegetation in the area is in the border zone between middle and northern boreal forest ecotones (Abrahamsen et al. 1977). The moose population is regulated mainly by hunting. Over the past twenty years, the annual cull of moose has increased from 1470 to 6447 (Statistisk sentralbyrå 1995, Jerstad 1996), and calf weights have decreased from $75-80 \mathrm{~kg}$ in 1970 to 55-60 in 1994 (Danielsen and Olsen 1994).

\section{Material and methods}

Three adult females with calves and one adult bull moose were chemically immobilized and marked with radio-collars (Televilt Int. AB, Sweden) during the winter of 1994. Their diets were monitored from May 11 to Aug 4, 1995, mainly between 0500-1000 and 1900-2400 when moose are most active (eg Cederlund 1989). To assure independent observations, there were always more than three days between observations of individual moose. Moose at their feeding sites were located by triangulation from a short distance. Precise location of each site was either established by direct observation of animals or by fresh feeding signs in the vegetation. The feeding sites (9-12 per individual, $n=44$ ), were examined after the moose had left. Two circular plots, each with a radius of $2 \mathrm{~m}$, were centered at spots of intensive moose browsing, and plant species fed on within plots recorded. Moose forage utilization was quantified as percent of feeding plots where a particular plant species showed evidence of feeding by moose (see Hjeljord et al. 1990 for a further description of methods). The availability of plants (percent horizontal coverage) was estimated within these circles and also at two randomly assigned circles within $50 \mathrm{~m}$ of the feeding station. We used the chi-square goodness of fit test to determine if the selected diet differed from expected if use was based only on availability. Preferences were calculated using the Bonferroni $Z$-statistic (Neu et al. 1974, Byers et al . 1984). Plants that were not recorded eaten by moose were excluded from the analysis, and plants that were present in small quantities were pooled as "other" plant species.

\section{Results}

Moose fed on 17 of the 35 species (excluding mosses) recorded as present at the feeding stations $(n=44)$. Birch Betula pubescens was fed on at $40 \%$ of the feeding sites, bilberry Vaccinium myrtillus at $13 \%$ and bog asphodel Narthecium ossifragum at $11 \%$, whereas other food plants made up a small portion of the diet (Table 1). The selected diet was different from one expected based on availability $\left(\chi^{2}=30.3, \mathrm{df}=3, p<0.005\right)$. Birch and bog asphodel were preferred, whereas bilberry and the other plant species were eaten less than expected based on availability (Table 1). 
Table 1. Food selection of moose during summer 1995 in Aust-Agder, southern Norway. Counts are number of plots where each plant species/group were used by moose. Food items chosen significantly more than expected based on availability (selection) are marked (+), and those chosen less than expected are marked (-). c.i. - confidence interval.

\begin{tabular}{lrccc}
\hline Species & Count & Used $(\%) \pm 90 \%$ c.i. & Selection & Expected \\
\hline Betula pubescens & 33 & $39.8 \pm 6.9$ & $(+)$ & 19.3 \\
Vaccinium myrtillus & 11 & $13.3 \pm 4.0$ & $(-)$ & 20.0 \\
Narthecium ossifragum & 9 & $10.8 \pm 1.7$ & $(+)$ & 4.2 \\
Others pooled & 30 & $36.1 \pm 11.0$ & $(-)$ & 54.5 \\
Vaccinium uliginosum & 5 & 6.0 & & 11.0 \\
Populus tremula & 4 & 4.8 & & 2.4 \\
Deschampsia flexuosa & 3 & 3.6 & & 7.6 \\
Salix spp. & 3 & 3.6 & & 0.9 \\
Athyrium filix-femina & 2 & 2.4 & & 5.6 \\
Juniperus communis & 2 & 2.4 & & 2.7 \\
Molinia coerulea & 2 & 2.4 & & 3.3 \\
Rubus idaeus & 2 & 2.4 & & 0.4 \\
Sorbus aucuparia & 2 & 2.4 & & 0.8 \\
Alnus incana & 1 & 1.2 & & 5.9 \\
Betula nana & 1 & 1.2 & \\
Poaceae & 1 & 1.2 & \\
Salix caprea & 1 & 1.2 & \\
Trichophorum cespitosum & 1 & 1.2 & & 5.2 \\
\hline
\end{tabular}

\section{Discussion}

Ruminants can ingest a variety of toxins in their diets (eg Mysterud and Østbye 1995), but some animals are prone to poisoning by some plants, eg domestic sheep Ovis aries eating the mushroom Cortinarius speciosissimus (Øverås et al. 1979). Bog asphodel causes severe kidney damage in sheep, goat Capra hircus and cattle Bos taurus (Flåøyen et al. 1995a, b, 1996, 1997), and as a result, the high intake of asphodel by moose was unexpected.

With reference to our feeding study, captive moose fed bog asphodel at the Norwegian Veterinary Institute developed kidney damages similar to that reported for domestic ruminants (A. Flåøyen, K. Handeland, T. Refsum, K. A. Ryeng and G. Stuve, unpubl.). White-coloured sheep also may develop the accompanying disease condition hepatogenous photosensitization ("alveld" in Norwegian), a hypersensitivity to UV radiation, when ingesting bog asphodel (Flyen 1993), but this is not likely to occur in moose because of the dark pigmentation.

Why then do moose in Agder prefer a "deadly" diet? Provenza (1995, 1996) claims ruminants may not be able to detect toxic substances if the digestive system does not give immediate negative feedback from ingestion of toxins. This could be the case for moose eating bog asphodel in Agder. Most attention on foraging ecology 
of free-ranging ruminants have focused on energy as a currency for optimization (eg Schoener 1971, Belovsky 1984). Generally little is known about the physiological effect of trace elements and secondary compounds on free-ranging ruminants.

The latin name of bog asphodel, "ossifragum", means "the one that makes bones fragile", suggesting a link between bog asphodel consumption and bone fragility. However, laboratory studies have not documented damage to the skeleton from high intake of this species (Nordal 1994). Rather, moose use of bog asphodel could be due to increasing moose populations and resultant competition for high-quality forage (Bjerga 1996), generally poor range conditions and by severe levels of acid rain and leakage of soil nutrients (Stabell 1993). Further analyses are needed to establish the causal relationship between these factors and moose health in the Agder counties.

Acknowledgements: We thank J. Colman, O. Hjeljord, I. Mysterud and three anonymous referees for commenting upon an earlier version of this paper.

\section{References}

Abrahamsen J., Jacobsen N. K., Kalliola R., Dahl E., Wilborg L. and Påhlsson L. 1977. [Ecotones of Norden]. Nordiska Utredningar Series B 34: 1-135. [In Norwegian]

Agder Skogeigarlag. 1987. [Area survey for Bygland municipality]. Agder Skogeigarlag, Agder: 1-47. [In Norwegian]

Belovsky G. E. 1984. Herbivore optimal foraging: a comparative test of three models. The American Naturalist 124: 97-115.

Bjerga M. 1996. [Feeding ecology of moose (Alces alces) along an altitudinal gradient in Aust-Agder]. M Sc thesis, University of Oslo, Oslo: 1-40. [In Norwegian]

Byers C. R., Steinhorst R. K. and Krausman P. R. 1984. Clarification of a technique for analysis of utilization-availability data. The Journal of Wildlife Management 48: 1050-1053.

Cederlund G. 1989. Activity patterns in moose and roe deer in a north boreal forest. Holarctic Ecology 12: $39-45$.

Cederlund G. and Markgren G. 1987. The development of the Swedish moose population, 1970-1983. Swedish Wildlife Research. Proceedings from the International Moose Symposium 2 (Part 2): $55-61$.

Danielsen I. and Olsen M. 1994. [The summer forage of moose in Aust-Agder]. M Sc thesis, Agricultural University of Norway, Ås: 1-51. [In Norwegian]

Fjeld P. E., Roer O. A., Danielsen I. and Arnemo J. M. 1997. [The moose project in Aust-Agder]. Technical report, Arendal: 1-106. [In Norwegian]

Flåøyen A. 1993. Studies of the Aetrology and Pathology of Alveld, with some comparisons to sporidesmin intoxication. $\mathrm{Ph} \mathrm{D}$ thesis, Norwegian College of Veterinary Medicine, Oslo: 1-24.

Flåøyen A., Bratberg B. and Grønstøl H. 1995a. Nephrotoxicity in lambs apparently caused by experimental feeding with Narthecium ossifragum. Veterinary Research Communications 19: $75-79$.

Flåøyen A., Bratberg B., Frøslie A. and Grønstøl H. 1995b. Nephrotoxicity and hepatotoxicity in calves apparently caused by experimental feeding with Narthecium ossifragum. Veterinary Research Communications 19: 63-73.

Flåøyen A., Bratberg B., Frøslie A., Grønstøl H., Langseth W., Mantle P. G. and von Krogh A. 1996. Further studies on the presence, qualities and effects of the toxic principles from Narthecium ossifragum plants. Veterinary Research Communications 20: 1-12. 
Flåøyen A., Bratberg B., Frøslie A., Grønstøl H., Langseth W., Mantle P. G. and von Krogh A. 1997. Nephrotoxicity in goats caused by dosing with a water extract from the stems of Narthecium ossifragum plants. Veterinary Research Communications 21: 499-506.

Hjeljord O., Hövik N. and Pedersen H. B. 1990. Choice of feeding sites by moose during summer, the influence of forest structure and plant phenology. Holarctic Ecology 13: 281-292.

Jerstad K. 1996. [Moose management in Vest-Agder]. Technical report, Fylkesmannen i Vest-Agder, Miljøvernavdelingen: 1-30. [In Norwegian]

Mysterud A. and Østbye E. 1995. Roe deer Capreolus capreolus feeding on yew Taxus baccata in relation to bilberry Vaccinium myrtillus density and snow depth. Wildlife Biology 1: 249-253.

Neu C. W., Byers C. R. and Peek J. M. 1974. A technique for analysis of utilization-availability data. The Journal of Wildlife Management 38: 541-545.

Nordal I. 1994. [The Lily family]. [In: Norges planter. L. Ryvarden, ed]. J. W. Cappelens forlag, København: 79-91. [In Norwegian]

Provenza F. D. 1995. Postingestive feedback as an elementary determinant of food preference and intake in ruminants. Journal of Range Management 48: 2-17.

Provenza F. D. 1996. Behavioral bases for varied diets in ruminants. Journal of Animal Science 74: 2010-2020.

Punsvik T. 1993. [Broken bones in moose in Agder - possible failure in the mineral balance?] Elgen 3: 76-77. [In Norwegian]

Punsvik T. 1994. [The moose in Agder has a lot of bone fractures]. Elgen 4: 82. [In Norwegian]

Sand H. 1996. Life history strategies in moose (Alces alces): geographical and temporal variation in body growth and reproduction. $\mathrm{Ph} \mathrm{D}$ thesis, Swedish University of Agricultural Sciences, Uppsala: $1-221$.

Schoener T. W. 1971. Theory of feeding strategies. Annual Review of Ecology and Systematics 2: 369-403.

Stabell B. 1993. A pre-industrial acidification event shown by diatom analyses of a recently acidified lake in southern Norway. Diatom Research 8: 145-158.

Statistisk sentralbyrå 1995. [Hunting statistics]. Statistisk sentralbyrå, Oslo: 1-50. [In Norwegian]

Øverås J., Ulvund M. J., Bakkevig S. and Eiken R. 1979. Poisoning in sheep induced by the mushroom Cortinarius speciosissimus. Acta Veterinaria Scandinavica 20: 148-150.

Received 26 September 1997, accepted 9 July 1998. 